УДК 351:629.7

DOI: https://doi.org/10.26642/jen-2020-3(93)-70-77

М.О. Псюк, здобувач
Державний університет «Житомирська політехніка»

\title{
Роль космічних агентств у формуванні державної політики розвитку космічної галузі
}

\author{
(Представлено: к.держ.упр., доц.. Сергієнко Л.В.)
}

\begin{abstract}
Враховуючи глобальні тенденції розвитку ринку космічних товарів та послуг, а також стратегічну важливість космічної галузі як мультиплікатора розвитку високотехнологічної інноваційної економіки, постає важливим питання перегляду й оптимізації значення космічних агентств у визначенні та формуванні пріоритетів розвитку державної космічної політики.

Світова космічна галузь швидко змінюється, здійснюючи перехід до четвертого етапу розвитку - побудови екосистеми «Нового космосу», яка характеризується стрімкою комерціалізацією космічного сектору, розширенням кола учасників галузі та наростаючою швидкістю впровадження інновачій.

На сьогодні вітчизняна космічна галузь потребує швидких та ефективних рімень щодо реформування начіональної космічної політики, виважених підходів до державного регулювання та управління галуззю з урахуванням глобальних трендів розвитку світового космічного сектору.

Ключові слова: космічна галузь; космічне агентство; міжнародна кооперація; державна політика; «Новий космос».
\end{abstract}

Актуальність теми. Глобалізація світової економіки, вдосконалення технологій та стрімкий ріст інновацій у високотехнологічних сферах поряд з перманентними кризовими економічними явищами, що супроводжуються оптимізацією витрат бюджетних урядових програм, призвели до зміни пріоритетів та підходів до організації державної політики у сфері космічної діяльності.

Посилення процесів комерціалізації космічної галузі, збільшення значення та кількості проєктів державно-приватного партнерства призвели до формування нових типів і форм взаємодії у галузі. Поява приватних компаній, розширення участі академічної спільноти, промисловості, громадського сектору, діджиталізація та інтенсифікація глобальної взаємодії знаменують входження світової космічної галузі у новий етап розвитку, який називають «Новим космосом», або четвертим етапом еволюції глобальної космічної галузі.

Враховуючи глобальні тенденції розвитку ринку космічних товарів та послуг, а також стратегічну важливість космічної галузі як мультиплікатора розвитку високотехнологічної інноваційної економіки, постає важливим питання перегляду та оптимізації значення космічних агентств у визначенні та формуванні пріоритетів розвитку державної космічної політики.

Аналіз останніх досліджень та публікації, на які спирається автор. Питанням формування стратегії, державного регулювання та формування і реалізації державної політики у сфері космічної діяльності присвячені публікації таких вітчизняних вчених та дослідників, як: О.П. Федоров, В.П. Горбулін, Е.І. Кузнєцов, О.В. Дегтярьов та інші. Питанням глобального розвитку космічного сектору, міжнародної взаємодії й тенденціям розвитку галузі присвячені публікації: К.В. Карпової, А.Мерхаба, М.Аінарді та ін. Проте, незважаючи на здобутки вчених у цій галузі, подальшого дослідження потребують питання актуалізації значення державних космічних агентств в умовах нового етапу розвитку світової космічної діяльності та їх впливу на формування ефективної державної політики у космічній галузі.

Метою статті $є$ дослідження значення космічних агентств у формуванні державної політики в галузі космічної діяльності, аналіз загальних тенденцій розвитку провідних космічних агентств світу та обгрунтування пріоритетів розвитку вітчизняної державної космічної політики.

Викладення основного матеріалу. На початкових етапах глобальної космічної діяльності національні уряди відігравали провідну роль у процесах становлення та розвитку більшості космічних підприємств і космічної галузі в цілому. В країнах з ринковою економікою приватний сектор $\epsilon$ підрядником державних програм, підтримуючи державні космічні проєкти. Значне державне фінансування історично заклало основи розвитку космічної галузі і сьогодні впливає на формування космічної політики, загальні тренди та структуру космічного сектору. Урядова космічна діяльність охоплює військові програми та цивільну діяльність, враховуючи прогнозування погоди, телекомунікації, наукові дослідження тощо. Окрім того, уряди, особливо у США та Європі, також закуповують комерційні космічні послуги, насамперед пускові, супутникові знімки, послуги зв’язку. Багато країн вбачає додаткові можливості для стимулювання економічного зростання за допомогою підтримки 
космічної діяльності та розвитку суміжних галузей. Протягом останнього десятиліття різні тенденції демонструють все більшу участь та типи залучення приватного сектору до розширення кола космічних ініціатив та програм.

Космічна індустрія пройшла декілька етапів свого розвитку, починаючи від перших астрономічних спостережень і відкриттів до сучасного етапу екосистеми «Нового космосу» та процесів комерціалізації космічної галузі. В цілому можна виокремити чотири загальні етапи розвитку (еволюції) космічної галузі (рис. 1).

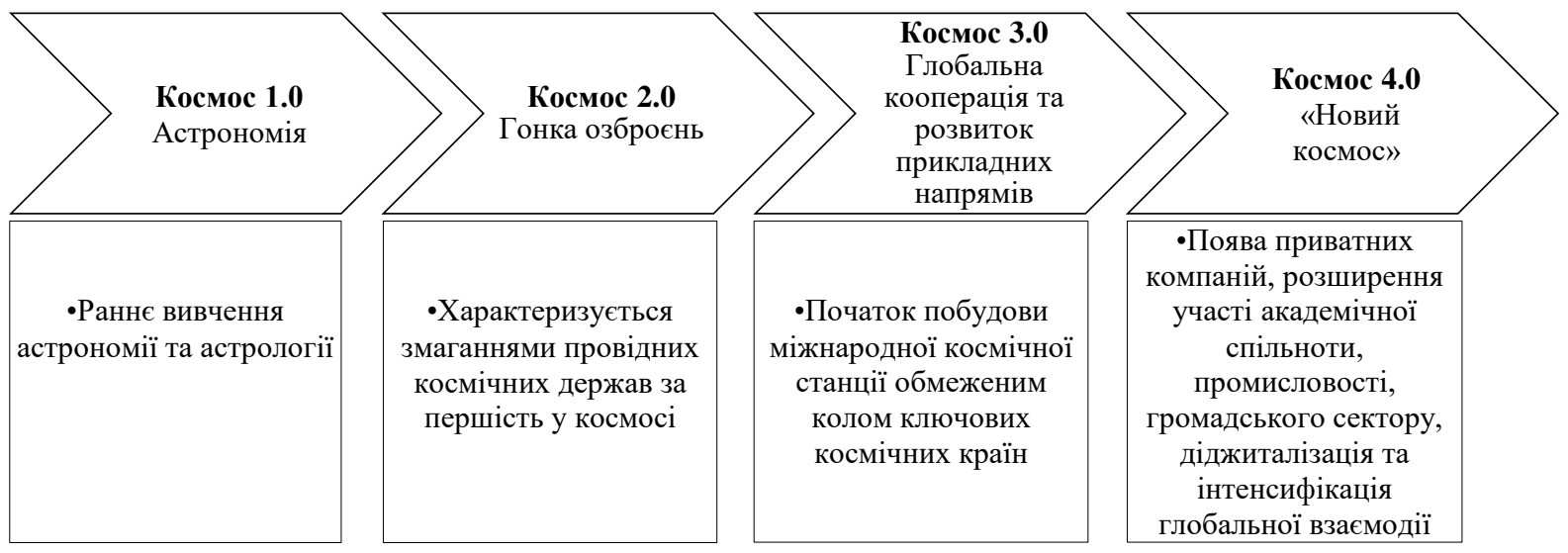

Рис. 1. Етапи еволюції космічної галузі

Перший етап розвитку космічної галузі займає період до початку ери практичної космонавтики, коли розвиток астрономії та подальші теоретичні наукові досягнення вчених XIX-XX ст. (праці К.Е. Ціолковського, Ю.В. Кондратюка та ін.) заклали основу для розробки перших зразків ракетної техніки та зробили можливим старт практичної космонавтики.

Другий етап розвитку галузі характеризується змаганнями провідних космічних держав за першість у космосі. Перші космічні агенції, створені в 1950-х рр., були головними замовниками та інвесторами космічних програм, які мали переважно військовий характер, а також були направлені на виконання політичних завдань демонстрації переваг та домінування двох головних антагоністичних політичних систем світу (СРСР та США). Агентства та урядові установи є як головними замовниками, так i підрядниками космічної галузі.

Початок третього етапу характеризується подальшим ускладненням космічних технологій, зростанням вартості розробки, виробництва та експлуатації космічної техніки. Держави $\epsilon$ переважаючими інвесторами в галузі, яка характеризується значною науко- та капіталоємністю. Відповідно почали змінюватися і підходи до планування та організації космічної діяльності, виникла потреба у налагодженні науково-технічних зв'язків та кооперації. Розпочинається широка співпраця між космічними агентствами різних країн, спільні проєкти та програми наукових досліджень, виробничої кооперації та освоєння космосу призводять до початку побудови у 1998 р. Міжнародної космічної станції (МКС).

Сьогодні світова космічна галузь швидко змінюється, здійснюючи перехід до четвертого етапу розвитку - побудови екосистеми «Нового космосу», яка характеризується стрімкою комерціалізацією космічного сектору, розширенням кола учасників галузі та наростаючою швидкістю впровадження інновацій. Змінюється і значення державних космічних агентств. На фоні стрімкого збільшення кількості приватних компаній (з 2011 по 2016 рр. кількість діючих компаній зросла на 157 \%), зайнятих у космічній галузі, зростає роль державно-приватної співпраці та демократизації галузі. Очевидно, що в подальшому значення національних космічних агентств дещо змінюватиметься. Хоча за агентствами і далі лишатиметься провідна роль у розвитку космічної індустрії, необхідно враховувати нові фактори і тенденції світової космічної галузі. У сучасних умовах напрями роботи національних агентств полягатимуть у здійсненні таких функцій:

- активізація національного космічного сектору - залучення приватних та державних гравців космічного сектору через надання доступу до інфраструктури, створення програм розвитку людського капіталу, надання цільового фінансування та просування космічного сектору;

- сприяння зростанню приватного капіталу в галузі та залучення іноземного бізнесу - агентство має ініціювати та підтримувати участь приватних компаній у національній космічній галузі й сприяти залученню іноземних інвестицій; 
- обговорення та чітке визначення візії та стратегії розвитку галузі - окреслення чітких напрямів розвитку для національного космічного сектору, встановлення довгострокових цілей розвитку та основних стратегічних пріоритетів, на яких агентство зосередить свої зусилля та ключові проєкти, що мають бути запущені;

- створення сприятливої нормативної бази - впровадження нормативно-правової бази, яка забезпечує юридичну визначеність та підтримку галузі, слугує стратегічним інструментом їі розвитку;

- підтримка розвитку національної галузі у міжнародному напрямі - підтримка міжнародної кооперації для інтеграції галузі в міжнародну космічну екосистему, забезпечення участі у великих міжнародних проєктах та розвиток національних технологій;

- управління стратегічними космічними напрямами, розвиток та управління стратегічними космічними видами діяльності, які не здійснюються повністю іншими суб'єктами національної космічної галузі [13].

У різних країнах національні космічні агентства, хоча й мають подібну основну мету та напрями діяльності, суттєво різняться за розміром та фінансуванням, правовим статусом та моделлю управління. Незважаючи на організаційно-правову модель діяльності національного агентства, його ефективність залежить від чіткості формування стратегічних цілей, національної політики в космічній галузі та їі підтримки урядом.

Однією 3 найбільш показових та ефективних форм міжнародної кооперації в космічній сфері $\epsilon$ приклад функціонування Європейського космічного агентства (СКА), яке було створене в 1975 р. i сьогодні налічує 22 держави-члени: Австрія, Бельгія, Чехія, Данія, Естонія, Фінляндія, Франція, Німеччина, Греція, Угорщина, Ірландія, Італія, Люксембург, Нідерланди, Норвегія, Польща, Португалія, Румунія, Іспанія, Швеція, Швейцарія та Великобританія. Словенія є асоційованим членом СКА. Канада бере участь у деяких проєктах за угодою про співпрацю. Болгарія, Хорватія, Кіпр, Мальта, Латвія, Литва та Словаччина мають угоди про співробітництво з СКА. Координуючи фінансові та інтелектуальні ресурси своїх членів (Бюджет СКА у 2018 р. закладено на рівні 5,6 млрд євро [7]), СКА може здійснювати програми й заходи, що виходять далеко за межі будь-якої єдиної європейської країни.

Метою СКА $є$ забезпечення мирних цілей у співпраці європейських держав у галузі космічних досліджень і технологій для їх використання з науковою метою та експлуатації космічних систем, а саме:

- розробка та впровадження довгострокової європейської космічної політики, рекомендація космічних цілей та узгодження політики держав-членів стосовно інших національних та міжнародних організацій і установ;

- розробка й впровадження заходів та програм у космічній галузі;

- координація європейської космічної програми та національних програм шляхом їх поступового й максимально повного інтегрування у європейську космічну програму, зокрема, що стосується розробки супутникових сервісів;

- розробка та впровадження, відповідно до космічної програми, промислової політики та рекомендацій державам-членам основ узгодженої промислової політики [8].

22 травня 2007 р. двадцять дев'ять європейських країн оприлюднили нову космічну політику, поєднавши підхід СКА з політикою окремих країн-членів Європейського Союзу, що створило спільну політичну основу для космічної діяльності в Європі [9]. Завдяки цьому документу Європейський Союз, ЄКА та його держави-члени зобов'язуються посилити координацію своєї діяльності й програм та організовувати відповідні напрями, що стосуються космосу.

Політика, спрямована на утвердження Європи як одного зі світових лідерів у сфері космічної галузі, визначила чотири пріоритетні напрями:

- космічні зміни клімату;

- внесок космосу в Лісабонську стратегію;

- космос та безпека;

- дослідження космосу [11].

Відповідно до виробленої політики, визнаючи актуальність космічної діяльності для суспільства та бізнесу, космічна політика СС має забезпечувати суспільні потреби у таких вимірах:

- соціальний вимір - стосується добробуту громадян, який залежить від екології та змін клімату, громадської безпеки і реагування на надзвичайні кризові ситуації;

- економічний вимір - пов'язаний зі спроможністю космічного сектору генерувати інновації, знання та продукти, які можна застосувати до масових ринків, завдяки підвищенню конкурентоспроможності європейських галузей і створенню нових робочих місць;

- стратегічний вимір - сприяє зміцненню європейської незалежності в галузі надання супутникової інформації європейським урядам та бізнесу, а також становлення СС як головного гравця в галузі розвитку глобальних наукових знань. У цьому контексті космічна політика СС вважається основою всієї стратегії «Свропа-2020», зокрема її провідної ініціативи «Промислова політика» [11]. 
Національне управління з аеронавтики і дослідження космічного простору (НАСА) - агентство уряду США, що відповідає за науково-технічні дослідження в галузі аеронавтики та космічних польотів. Створене у відповідь на ранні радянські космічні досягнення, НАСА було побудовано на базі Національного консультативного комітету з питань аеронавтики та інших урядових організацій 3 метою реалізації американських досліджень у галузі цивільних аерокосмічних досліджень.

Традиційно НАСА розпоряджається найбільшими у світовій космічній галузі бюджетами - у 2018 фінансовому році загальний бюджет НАСА становив 19,5 млрд дол. США [10], а загальні урядові витрати США у тому ж році були більшими за сумарні космічні бюджети урядів інших країн світу (11,6 та 9,1% відповідно у загальній структурі витрат світової космічної економіки) [5].

Національна космічна політика США охоплює всі космічні сектори - комерційну, цивільну та національну безпеку, а також міжсекторальну космічну діяльність. Політика у сфері космічного простору США встановлюється як президентськими директивами, так і відповідними законами. В цілому нормативно-правове регулювання галузі в США містить складну систему відповідних актів та їх взаємоузгодження. Директиви президента залишаються чинними до тих пір, поки майбутній президент не перегляне їх. Так на сьогодні діє сукупність директив, виданих президентами Джорджем Бушем (2001-2009 pр.), Бараком Обамою (2009-2017 рр.) та Дональдом Трампом (з 2017 р.).

Найновішу повну національну космічну політику президента опублікував Барак Обама 28 червня 2010 р. Ця політика залишається чинною, поки інший президент не змінить ії. Президент Дональд Трамп змінив дві позиції з цього питання, але решта поки що залишається незмінною. В цілому він підписав чотири директиви космічної політики та Національну космічну стратегію [4]:

- Директива про космічну політику 1 спрямовує НАСА повернути людей на поверхню місяця як трамплін до дослідження Марса замість підкорення астероїду, як і планувала адміністрація Обами;

- Національна космічна стратегія визначає стратегію реалізації політики національної безпеки, комерційного та цивільного простору;

- Директива про космічну політику 2 встановлює визначення Департаменту торгівлі як «єдиного вікна» комерційних правил у сфері космосу;

- Директива про космічну політику 3 встановлює ролі та відповідальність НАСА щодо обізнаності про космічну ситуацію та управління космічним рухом;

- Директива про космічну політику 4 пропонує створити космічні сили США у складі ВПС США.

В цілому на сьогодні космічна політика США спрямована на утвердження лідерства США у космічній галузі, забезпечення незалежності американської пілотованої космонавтики, розвиток місячних та марсіанських програм.

У Російській Федерації роль національного космічного агентства виконує «Роскосмос» - державна корпорація, створена в серпні 2015 р. шляхом перетворення Федерального російського космічного агентства «Роскосмос», для проведення комплексної реформи ракетно-космічної галузі Росії. Держкорпорація «Роскосмос» забезпечує реалізацію державної політики в галузі космічної діяльності та iii нормативно-правове регулювання, а також розміщує замовлення на розробку, виробництво і поставку космічної техніки і об’єктів космічної інфраструктури. У функції державної корпорації також входить розвиток міжнародного співробітництва у космічній сфері та створення умов для використання результатів космічної діяльності в соціально-економічному розвитку Росії [16].

Космічна галузь Росії є однією 3 найбільш розвинених світових космічних галузей та бере свій початок з радянської космічної програми. Росія здатна забезпечувати повний цикл космічного виробництва, має декілька космодромів та підтримує власний сегмент на МКС. У 2018 р. «Роскосмос» забезпечив пуски 20 ракет-носіїв 3 космічними апаратами (17 \% від усіх світових пусків у 2018 р.), російське орбітальне угруповання космічних апаратів соціально-економічного, наукового і подвійного призначення на кінець 2018 р. нараховувало 89 космічних апаратів [14].

Напрями космічної діяльності Росії викладено у Федеральній космічній програмі 2016-2025, метою якої є забезпечення державної політики в галузі космічної діяльності на основі формування і підтримки необхідного складу орбітального угруповання космічних апаратів, що забезпечують надання послуг в інтересах соціально-економічної сфери, науки і міжнародної співпраці, зокрема 3 метою захисту населення і територій від надзвичайних ситуацій природного і техногенного характеру, а також реалізації пілотованої програми, створення засобів виведення та технічних засобів, створення науково-технічного доробку для перспективних космічних комплексів і систем. Передбачається два етапи реалізації програми. На першому етапі (2016-2020 рр.) здійснюється нарощування орбітального угруповання космічних апаратів соціально-економічного і наукового призначення до мінімально необхідного складу переважно космічними апаратами, створеними у попередній період дії програми, випереджальне створення ключових технологій, елементів і цільових приладів для космічних комплексів, розроблення яких планується відповідно до програми, модернізація і технічне переозброєння в мінімально необхідному обсязі виробничо-технологічної та експериментальної баз ракетно-космічної галузі, що дозволяють створювати ракетно-космічну техніку світового рівня. На другому етапі (2021-2025 pp.) 
планується здійснювати підтримання мінімально необхідного складу орбітального угруповання космічних апаратів, часткове переоснащення іiі космічними апаратами нового покоління 3 характеристиками, відповідними або такими, що перевищують характеристики кращих світових аналогів, створення окремих ключових технологій, елементів і цільових приладів для найбільш пріоритетних космічних комплексів, розробка яких очікується після 2025 p.

Для досягнення головних цілей державної політики в галузі космічної діяльності Росії основами державної політики установлено такі пріоритети космічної діяльності:

- діяльність, пов'язана із забезпеченням гарантованого доступу Російської Федерації в космос зі своєї території, з розвитком і використанням космічної техніки, технологій, робіт і послуг в інтересах соціально-економічної сфери Російської Федерації, з метою оборони країни і безпеки держави, а також 3 розвитком ракетно-космічної галузі та виконанням міжнародних зобов'язань;

- діяльність, пов'язана зі створенням виробів ракетно-космічної техніки в інтересах науки;

- діяльність, пов'язана зі здійсненням пілотованих польотів, враховуючи створення науковотехнічного доробку для здійснення проєктів у межах міжнародної кооперації [17].

В цілому можна констатувати, що космічна галузь Росії має значний потенціал для розвитку, однак наростаюча конкуренція з боку провідних світових космічних державних та приватних компаній може похитнути позиції держави на світовому ринку космічних послуг.

Китайська космічна програма є однією з найскладніших і найбільш непрозорих у світі, водночас у державі сформована та розвивається одна 3 найбільш динамічних та самодостатніх космічних галузей. Космічна програма Китаю бере початок 31956 р. На сьогодні Китай володіє розвиненою інфраструктурою, що складається 3 космічних прикладних систем різноманітного призначення (телекомунікації, дистанційне зондування Землі, навігація), наукових космічних апаратів і наземної інфраструктури, що враховує чотири космодроми, систему наземних і корабельних станцій спостереження і керування польотами. Китай також $є$ третьою державою світу, які мають можливість самостійно здійснювати пілотовані польоти. Окрім цього, Китай користується багатьма передовими технологіями, такими як запуск декількох космічних апаратів однією ракетою-носієм, криогенні двигуни, технології входу в атмосферу тощо. [15].

У вересні 1992 р. уряд Китаю ухвалив рішення про реалізацію пілотованої космічної програми $\mathrm{i}$ прописав «трикрокову стратегію» розвитку:

- перший крок - запустити пілотований космічний корабель, створити інтегровані експериментальні пілотовані космічні кораблі, а також провести експерименти із застосуванням космічної техніки;

- другий крок - здійснити технологічний прорив у інших видах діяльності, а також у зближенні та стикуванні пілотованих космічних кораблів і космічних апаратів, запустити космічну лабораторію та ін.;

- третій крок - створити космічну станцію та запропонувати рішення для космічних досягнень більшого масштабу на довгостроковій основі.

Космічна програма «Пілотований Китай» складається 3 чотирнадцяти систем, в яких діють понад 110 підрозділів та підприємств [1].

Багато аспектів організації і управління космічною діяльністю в Китаї залишається невідомими, однак, початковий вектор розвитку космічної діяльності задається Центральною військовою комісією Компартії Китаю. Прагнення Китаю до відкритості космічної сфери, підвищення ефективності космічної діяльності через створення інтегрованої структури i, можливо, бажання наблизитися до організаційної моделі інших потужних космічних держав призвело до створення Китайського національного космічного управління (КНКУ), відповідального зокрема за цивільну космічну діяльність і підписання міжнародних договорів. Створене в червні 1993 р. КНКУ є спеціалізованим агентством з управління космічною програмою Китаю. Основним обов'язком КНКУ є єдине управління космічною програмою Китаю, враховуючи стратегію розвитку, планування, загальні технології, дослідження та виробництво, будівництво інфраструктури, організацію та виконання польотів, просування, міжнародне співробітництво та випуск новин тощо. КНКУ складається з відділу інтегрованого планування та управління, відділу з наукових програм та контролю якості, відділу використання та розвитку, відділу будівництва інфраструктури та підрозділу системи тощо [6].

Основною особливістю системи управління і ресурсного забезпечення космічної діяльності в Китаї $\epsilon$ те, що космос - важлива складова національних інтересів у цивільній і військовій сферах, які встановлюються державою, тому присутність держави має для китайської космічної програми абсолютний характер. Китайська космічна промисловість належить державі і дуже зрощена 3 публічними органами управління космічною діяльністю. Комерціалізація космічної промисловості здійснюється в дуже обмеженій формі, коли китайським організаціям видається ліцензія на міжнародну комерційну космічну діяльність, здатну приносити інвестиції.

Державна підтримка галузі поєднується з використанням ринкових принципів. У зв'язку з цим варто виокремити здійснену в кінці 1990-х рр. реорганізацію космічної промисловості, спрямовану на врахування механізму конкуренції: колишня Китайська корпорація космічної промисловості, яка займала 
монопольне становище у своїй області, реорганізована в дві корпорації: Китайську корпорацію космічного обладнання та електроніки і Китайську корпорацію космічної науки й технології. Обидві корпорації є державними комерційними підприємствами і мають структуру, що дозволяє здійснювати в повному обсязі наукові дослідження, розробки і виробництво як військової, так і цивільної космічної та іншої високотехнологічної продукції [15].

Космічну політику Канади впроваджує Канадське космічне агентство (ККА), яке зосереджує свою діяльність та ресурси на трьох основних напрямах [3]:

- космічні дослідження - участь у місіях астронавтів, астрономія та вивчення планет, виконання та підтримка наукових космічних досліджень;

- використання космосу: супутникові спостереження Землі, збір та обробка космічних даних;

- космічна наука та технології - розробка інноваційних космічних технологій та сервісів.

ККА займає важливе місце серед багатьох космічних агентств у світі та має велику кількість партнерських відносин 3 урядом, промисловістю, науковим середовищем та міжнародними організаціями.

Канадський космічний сектор є важливою частиною економіки - у 2018 р. сукупний дохід у канадському космічному секторі був на рівні 5,7 млрд дол. [12]. Середньорічний темп зростання космічного сектору між 2014 та 2018 рр. становив 1,3\% (рис. 2).

У 2018 р. космічний сектор вніс 2,5 млрд дол. у ВВП Канади, 20891 робоче місце функціонувало в загальній економіці країни завдяки роботі космічної галузі, а кожен долар, який космічний сектор вніс у ВВП, призводив до додаткового внеску в ВВП від 0,9 дол. для загальної економіки країни.

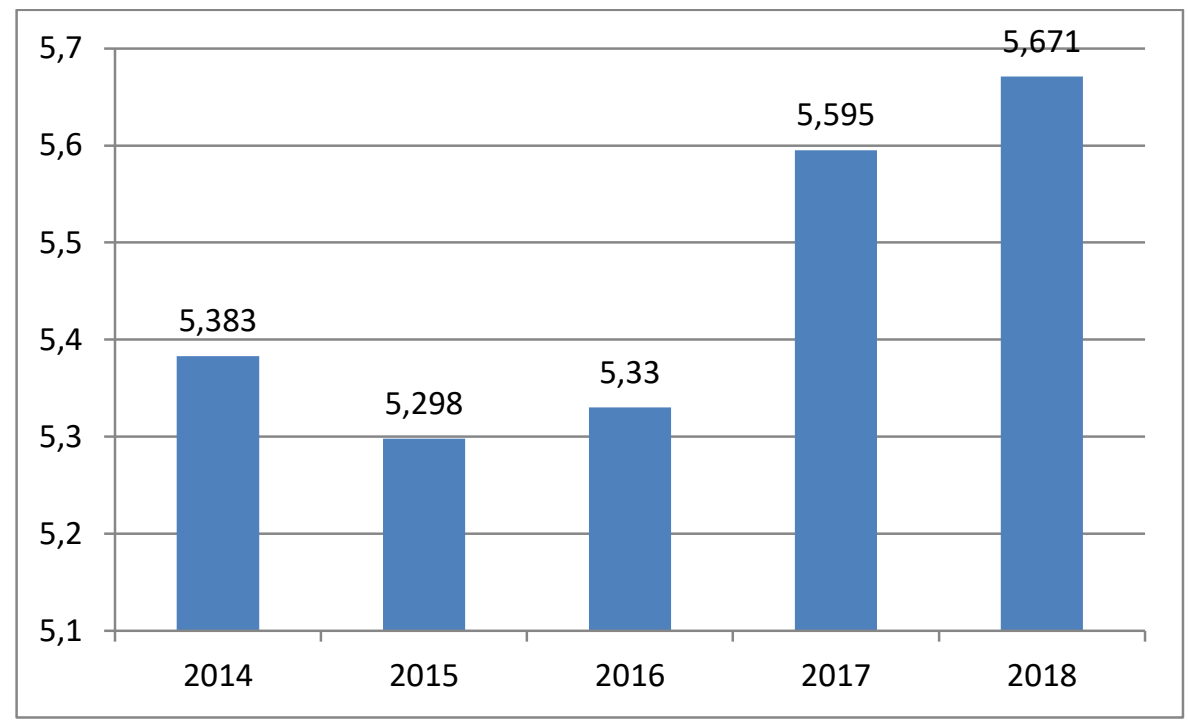

Рис. 2. Доходи від космічної діяльності в Канаді протягом 2014-2018 рр., млрд дол. [12]

Формуючи основи національної космічної політики, ККА виокремлює такі принципи її побудови [2]:

1. Перш за все інтереси Канади - національний суверенітет, безпека та процвітання стануть ключовими рушійними силами Канади у космосі. Першим пріоритетом у Канаді має бути ефективне використання космосу для підтримки цих інтересів;

2. Приватний сектор на передовій космічної діяльності. Оскільки космос дає все більше комерційних можливостей, уряд зосереджує увагу на підтримці космічної галузі в інноваціях, необхідних для впровадження на ринок передових технологій, що відповідають національним інтересам.

3. Прогрес через партнерські стосунки - діяльність зосереджується на побудові партнерських стосунків та розвитку співпраці з міжнародними партнерами для взаємної вигоди та отримання послуг та технологій, які інакше були б недоступні. Водночас ефективні заходи контролю за експортом i регуляторні заходи продовжуватимуть захищати канадські технології та дані від крадіжок або потрапляння в руки «ворожих інтересів»;

4. Удосконалення ключових напрямів - Канада має успіх у низці областей космічних технологій від телекомунікацій до дистанційного зондування та робототехніки, які отримують першочергову підтримку, при цьому також постійно відстежуються нові та перспективні технологічні ніші;

5. Підтримка та мотивація - увага та зусилля зосереджуються на мотивації громади, оскільки космос $\epsilon$ надзвичайно видимим та дієвим засобом мотивації молодих канадців продовжувати кар'єру в галузі науки, техніки та математики. ККА, працюючи з промисловістю, університетами та коледжами, велику увагу приділяє працевлаштуванню та підтримці висококваліфікованого персоналу в галузі. 
Для підвищення ефективності стратегічного планування та оперативного управління космічною галуззю, відповідно до основ національної космічної політики, в Канаді передбачено створення Канадської консультативної ради з питань космічного простору.

Виходячи із загальних тенденцій розвитку провідних космічних агентств світу, можна зробити висновок, що в майбутньому буде зберігатися домінуюча роль державної участі у визначенні загальних положень розвитку космічної діяльності, формуванні бюджету національних космічних програм, а також у загальному механізмі розподілу фінансових ресурсів, який здійснюватиметься через спеціалізовані державні структури, з незмінною часткою присутності сектора державної безпеки. Одночасно в світовій космічній галузі активно розвиватимуться процеси кооперації та комерціалізації, знаменуючи подальший перехід до четвертого етапу розвитку - побудови екосистеми «Нового космосу». Відтак можемо окреслити такі пріоритети розвитку державної космічної політики в Україні:

- комерціалізації галузі, зокрема через забезпечення швидкої корпоратизації державних підприємств галузі, які знаходяться у сфері управління Державного космічного агентства України;

- залучення бізнес-сектору до реалізації бізнес-проєктів як безпосередньо в області виробництва ракетно-космічної техніки, так і під час виробництва обладнання та комплектуючих;

- збільшення ролі агентства у просуванні, налагодженні контактів та забезпеченні участі українських гравців космічної галузі в міжнародних програмах та проєктах, розвиток міжнародної науково-технічної та виробничої кооперації;

- розвиток державно-приватного партнерства в галузі шляхом забезпечення інвестиційних гарантій та залучення інвестиційних ресурсів для підприємств, які працюють у галузі;

- державна підтримка галузі прямими методами через забезпечення функціонування системи державного замовлення, зокрема оборонного;

- державна підтримка галузі непрямими методами через надання підприємствам космічної галузі податкових та митних пільг під реалізацію міжнародних проєктів, державних гарантій тощо;

- законодавча підтримка галузі, створення умов для безперешкодного входження приватного капіталу в галузь, зокрема іноземного, зняття неефективних ліцензійних обмежень;

- розвиток ключових компетенцій - в умовах обмеженого фінансування та глобальної конкуренції визначення та пріоритетна підтримка ключових стратегічних секторів космічної галузі, в яких на цей момент ще зберігається науково-технічний та виробничий потенціал;

- розвиток людського потенціалу - забезпечення підготовки та перепідготовки висококваліфікованих кадрів для космічної промисловості, збереження наукового потенціалу галузі.

Дотримання означених пріоритетів під час вироблення державної політики у сфері космічної діяльності закладе основи для побудови ефективної стратегії розвитку галузі відповідно до сучасних тенденцій світового космічного сектору та дозволить у подальшому розвивати та реалізовувати дієві механізми державного регулювання вітчизняної космічної галузі.

Висновки та перспективи подальших досліджень. Провідні космічні держави світу поступово здійснюють перехід до четвертого еволюційного етапу розвитку космічної галузі, так званої економіки «Нового космосу», що дозволить їм значно посилити фінансову базу галузі, забезпечити стратегічну конкурентоздатність та збільшити темпи зростання науково-технічного потенціалу і виробничої спроможності галузі, закріпитися в існуючих і перспективних ринкових нішах. У таких умовах вітчизняна космічна галузь потребує швидких та ефективних рішень щодо реформування національної космічної політики, виважених підходів до державного регулювання та управління галуззю під час врахування глобальних трендів розвитку світового космічного сектору.

\section{Список використаної літератури:}

1. About CMS [Електронний ресурс]. - Режим доступу : http://en.cmse.gov.cn/aboutcms.

2. Canada's Space Policy Framework. Launching the next generation [Електронний ресурс]. - Режим доступу : https://www.asc-csa.gc.ca/pdf/eng/publications/space-policy/canadas-space-policy-framework.pdf.

3. Canadian Space Agency. Organization [Електронний pecypc]. - Режим доступу : https://www.asccsa.gc.ca/eng/about/csa-organization.asp.

4. Civil space policy documents https://spacepolicyonline.com/topics/civil.

5. Commercial-space-activities [Електронний pecypc]. $\quad$ - $\quad$ Режим доступу https://spacepolicyonline.com/topics/commercial-space-activities/.

6. CSMA [Електронний ресурс]. - Режим доступу : http://en.cmse.gov.cn/management/cmsa.

7. ESA budget 2018 [Електронний pecypc]. - Pежим доступу : https://www.esa.int/ESA_Multimedia/Images/2018/01/ESA_budget_2018.

8. ESA facts [Електронний ресурс]. - Режим доступу : http://www.esa.int/About_Us/Corporate_news/ESA facts.

9. European Space Policy [Електронний pecypc]. ${ }_{-}$Режим доступу : http://www.esa.int/About_Us/Corporate_news/European_Space_Policy. 
10. National Aeronautics and Space Administration. FY 2019 Budget Estimates [Електронний ресурс]. - Режим доступу : https://www.nasa.gov/sites/default/files/atoms/files/nasa_fy_2019_budget_overview.pdf.

11. Space market uptake in Europe. Directorate-General for Internal Policies of the Union (European Parliament) [Електронний ресурс]. - Режим доступу : https://op.europa.eu/en/publication-detail/-/publication/9fe64a00-c00f11e5-9e54-01aa75ed71a1/language-en.

12. State of the Canadian Space Sector REPORT 2019. Facts and Figures 2018 [Електронний ресурс]. - Режим доступу : https://www.asc-csa.gc.ca/pdf/eng/publications/2019-state-canadian-space-sector-v2.pdf.

13. The Space Agency of the Future. The space agency in the era of Space 4.0: A key space sector enabler [Електронний pecypc]. - Режим доступу : https://www.adlittle.com/sites/default/files/viewpoints/adl_space_agency-min.pdf.

14. Годовой отчет Государственной корпорации по космической деятельности «Роскосмос» за 2018 год [Електронний ресурс]. - Режим доступу https://www.roscosmos.ru/media/img/2019/august/godovoi.otcet.goskorporazii.roskosmos.2018.g.pdf.

15. Карпова К.В. Системы управления ракетно-космической промышленностью в зарубежных странах / К.В. Карпова // Транспортное дело России. - 2013. - С. 249-253 [Електронний ресурс]. - Режим доступу : https://cyberleninka.ru/article/n/sistemy-upravleniya-raketno-kosmicheskoi-promyshlennostyu-v-zarubezhnyhstranah/viewer.

16. Общая информация и структура Госкорпорации [Електронний ресурс]. - Режим доступу : https://www.roscosmos.ru/219/.

17. Приоритеты космической деятельности [Електронний ресурс]. - Режим доступу : https://www.roscosmos.ru/22347/

\section{References:}

1. About CMS, [Online], available at: http://en.cmse.gov.cn/aboutcms

2. Canada's Space Policy Framework. Launching the next generation, [Online], available at: https://www.asccsa.gc.ca/pdf/eng/publications/space-policy/canadas-space-policy-framework.pdf

3. Canadian Space Agency. Organization, [Online], available at: https://www.asc-csa.gc.ca/eng/about/csaorganization.asp

4. Civil space policy documents, [Online], available at: https://spacepolicyonline.com/topics/civi]

5. Commercial-space-activities, [Online], available at: https://spacepolicyonline.com/topics/commercial-spaceactivities/

6. CSMA, [Online], available at: http://en.cmse.gov.cn/management/cmsa

7. ESA budget 2018, [Online], available at: https://www.esa.int/ESA_Multimedia/Images/2018/01/ESA_budget_2018

8. ESA facts, [Online], available at: http://www.esa.int/About_Us/Corporate_news/ESA_facts

9. European Space [Online], Policy, available at: http://www.esa.int/About_Us/Corporate_news/European_Space_Policy

10. National Aeronautics and Space Administration. FY 2019 Budget Estimates, [Online], available at: https://www.nasa.gov/sites/default/files/atoms/files/nasa_fy_2019_budget_overview.pdf

11. Space market uptake in Europe. Directorate-General for Internal Policies of the Union (European Parliament), [Online], available at: https://op.europa.eu/en/publication-detail/-/publication/9fe64a00-c00f-11e5-9e5401aa75ed71a1/language-en

12. State of the Canadian Space Sector REPORT 2019. Facts and Figures 2018, [Online], available at: https://www.asc-csa.gc.ca/pdf/eng/publications/2019-state-canadian-space-sector-v2.pdf

13. The Space Agency of the Future. The space agency in the era of Space 4.0: A key space sector enabler, [Online], available at: https://www.adlittle.com/sites/default/files/viewpoints/adl_space_agency-min.pdf

14. Godovoi otchet Gosudarstvennoi korporatsii po kosmicheskoi deyatel'nosti «Roskosmos» za 2018 god, [Online], available at: https://www.roscosmos.ru/media/img/2019/august/godovoi.otcet.goskorporazii.roskosmos.2018.g.pdf.

15. Karpova, K.V. (2013), «Sistemy upravleniya raketno-kosmicheskoi promyshlennost'yu v zarubezhnykh stranakh», Transportnoe delo Rossii, pp. 249-253, [Online], available at: https://cyberleninka.ru/article/n/sistemy-upravleniyaraketno-kosmicheskoi-promyshlennostyu-v-zarubezhnyh-stranah/viewer.

16. Obshchaya informatsiya i struktura Goskorporatsii, [Online], available at: https://www.roscosmos.ru/219/

17. Prioritety kosmicheskoi deyatel'nosti, [Online], available at: https://www.roscosmos.ru/22347/

Псюк Михайло Олександрович - здобувач Державного університету «Житомирська політехніка».

Наукові інтереси:

- державне управління;

- державне регулювання та управління у забезпеченні розвитку космічної галузі.

http://orcid.org/0000-0003-3786-7081. 